\title{
Front Matter: Volume 10971
}

, "Front Matter: Volume 10971," Proc. SPIE 10971, Nondestructive Characterization and Monitoring of Advanced Materials, Aerospace, Civil Infrastructure, and Transportation XIII, 1097101 (3 July 2019); doi: $10.1117 / 12.2534551$

SPIE Event: SPIE Smart Structures + Nondestructive Evaluation, 2019, Denver, Colorado, United States 


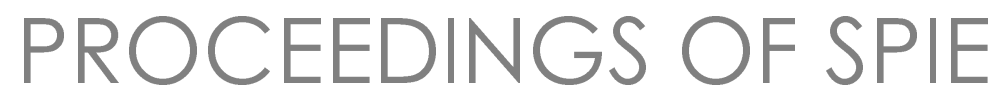

\title{
Nondestructive Characterization and Monitoring of Advanced Materials, Aerospace, Civil Infrastructure, and Transportation XIII
}

\author{
Andrew L. Gyekenyesi \\ Tzu-Yang Yu \\ H. Felix Wu \\ Peter J. Shull \\ Editors
}

\author{
4-7 March 2019 \\ Denver, Colorado, United States
}

Sponsored by

SPIE

Cosponsored by

Oz Optics, Ltd. (United States) · Polytec, Inc. (United States)

Cooperating Organizations

Jet Propulsion Laboratory (United States) · Colorado Photonics Industry Association (United States)

Published by

SPIE 
The papers in this volume were part of the technical conference cited on the cover and title page. Papers were selected and subject to review by the editors and conference program committee. Some conference presentations may not be available for publication. Additional papers and presentation recordings may be available online in the SPIE Digital Library at SPIEDigitalLibrary.org.

The papers reflect the work and thoughts of the authors and are published herein as submitted. The publisher is not responsible for the validity of the information or for any outcomes resulting from reliance thereon.

Please use the following format to cite material from these proceedings:

Author(s), "Title of Paper," in Nondestructive Characterization and Monitoring of Advanced Materials, Aerospace, Civil Infrastructure, and Transportation XIII, edited by Andrew L. Gyekenyesi, TzU-Yang YU, H. Felix WU, Peter J. Shull, Proceedings of SPIE Vol. 10971 (SPIE, Bellingham, WA, 2019) Seven-digit Article CID Number.

ISSN: 0277-786X

ISSN: 1996-756X (electronic)

ISBN: 9781510625976

ISBN: 9781510625983 (electronic)

Published by

SPIE

P.O. Box 10, Bellingham, Washington 98227-0010 USA

Telephone +13606763290 (Pacific Time) · Fax +1 3606471445

SPIE.org

Copyright (c) 2019, Society of Photo-Optical Instrumentation Engineers.

Copying of material in this book for internal or personal use, or for the internal or personal use of specific clients, beyond the fair use provisions granted by the U.S. Copyright Law is authorized by SPIE subject to payment of copying fees. The Transactional Reporting Service base fee for this volume is $\$ 18.00$ per article (or portion thereof), which should be paid directly to the Copyright Clearance Center (CCC), 222 Rosewood Drive, Danvers, MA 01923. Payment may also be made electronically through CCC Online at copyright.com. Other copying for republication, resale, advertising or promotion, or any form of systematic or multiple reproduction of any material in this book is prohibited except with permission in writing from the publisher. The CCC fee code is 0277 $786 \mathrm{X} / 19 / \$ 18.00$.

Printed in the United States of America by Curran Associates, Inc., under license from SPIE.

Publication of record for individual papers is online in the SPIE Digital Library.

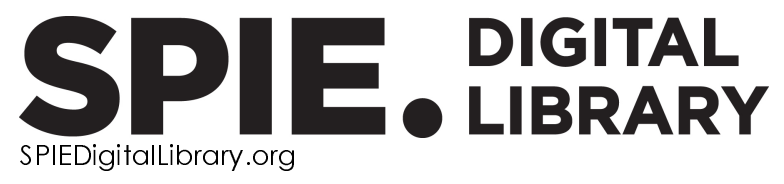

Paper Numbering: Proceedings of SPIE follow an e-First publication model. A unique citation identifier (CID) number is assigned to each article at the time of publication. Utilization of CIDs allows articles to be fully citable as soon as they are published online, and connects the same identifier to all online and print versions of the publication. SPIE uses a seven-digit CID article numbering system structured as follows:

- The first five digits correspond to the SPIE volume number.

- The last two digits indicate publication order within the volume using a Base 36 numbering system employing both numerals and letters. These two-number sets start with 00, 01, 02, 03, 04, 05, 06, 07, 08, 09, 0A, OB ... 0Z, followed by 10-1Z, 20-2Z, etc. The CID Number appears on each page of the manuscript. 


\title{
Contents
}

\author{
ix Authors \\ xi Conference Committee
}

SHM-NDE OF CIVIL STRUCTURES/INFRASTRUCTURE I

$1097103 \quad$ Long-term wireless monitoring solution for the risk management of highway retaining walls [10971-1]

1097104 Optimized spatial placement of structural bolts in connections for effective ultrasonic inspection [10971-2]

$1097105 \quad$ Electromagnetic sensing of a subsurface metallic object at different depths [10971-3]

1097106 Characterization of textile effects on concrete panel using synthetic aperture radar imaging [10971-4]

SHM-NDE OF CIVIL STRUCTURES/INFRASTRUCTURE II

$1097107 \quad$ Effect of rebar geometries on ultrasonic waves propagation in reinforced concrete structures using finite element method [10971-5]

\section{SHM-NDE OF CIVIL STRUCTURES/INFRASTRUCTURE III}

10971 OC Bistable wind-induced vibration energy harvester for self-powered wireless sensors in smart bridge monitoring systems [10971-11]

10971 OD Defecting damages and stress changes in concrete structures using coda wave interferometry [10971-12]

10971 OE 3D InspectionNet: a deep 3D convolutional neural networks based approach for 3D defect detection on concrete columns [10971-13]

$109710 G$ Stress measurement of a pressurized vessel using candle soot nanocomposite based photoacoustic excitation [10971-15]

$10971 \mathrm{OH} \quad$ Acoustic emission monitoring of strengthened steel bridges: Inferring the mechanical behavior of post-installed shear connectors [10971-16]

$1097101 \quad$ Concrete performance prediction using boosting smooth transition regression trees (BooST) [10971-17] 
SHM-NDE SCIENCE AND THEORY I

$10971 \mathrm{~J} \quad$ Verification of probabilistic risk assessment method AMETA for aircraft fatigue life management [10971-18]

10971 OK Nondestructive evaluation of coated steel plates using a 94GHz microwave interferometer [10971-19]

$10971 \mathrm{OL} \quad$ Assessing reliability of NDE flaw detection using smaller number of demonstration data points [10971-20]

10971 OM NDE flaw detectability validation using smaller number of signal response data-points [10971-21]

$109710 N \quad$ In-line quality control using dimensional metrology of 3D metal parts printed by laser beam melting [10971-22]

\section{SHM-NDE OF CIVIL STRUCTURES/INFRASTRUCTURE IV}

$1097100 \quad$ Structural health monitoring using embedded magnetic shape memory alloys for magnetic sensing [10971-23]

10971 OP Control of thermal deflection in concrete structures using iron-based shape memory alloys [10971-24]

10971 OR Non-contact assessment of thermal damage of concrete using a nonlinear wave modulation technique [10971-26]

\section{SHM-NDE OF CIVIL STRUCTURES/INFRASTRUCTURE V}

10971 OS Characterization of dielectric constant of masonry wall using synthetic aperture radar imaging [10971-27]

10971 OT Automated construction of bridge condition inventory using natural language processing and historical inspection reports [10971-28]

10971 OU Defection of grain angle in wood specimens using synthetic aperture radar imaging [10971-29]

10971 OV IOT-powered remote sensing system and portable tools for real-time evaluation of strain imaging sheets affixed to old outdoor structures [10971-30]

10971 OW Machine vision-based concrete beam crack pattern identification using fractal theory [10971-31] 
$109710 X \quad$ Grain effect on the accuracy of defect detection in wood structure by using acoustic-laser technique [10971-32]

10971 OY Piezoelectric cement sensor and impedance analysis for concrete health monitoring [10971-33]

\section{SHM-NDE SCIENCE AND THEORY II}

$109710 Z \quad$ Bayesian estimation of defect patterns in composite materials using through-thickness dielectric measurements [10971-34]

$1097111 \quad$ Electrical properties of copper-loaded polymer composites [10971-36]

1097112 Soft-matter damage detection systems for electronics and structures [10971-37]

1097113 Evaluating the shadow or glare effects in thermography for non-destructive testing and evaluation [10971-38]

\section{SHM-NDE ULTRASONICS I}

1097114 The identification of accurate and computationally efficient arrival time pick-up method for acoustic tomography [10971-39]

1097115 An experimental evaluation of Helmholtz potentials as a source of acoustic emission due to fatigue crack [10971-40]

$109716 \quad$ Nonlinear phased array imaging of flaws a modulation technique [10971-41]

109717 Development of nonlinear acoustic and air-coupled techniques for non-destructive testing [10971-42]

\section{SHM-NDE OF COMPOSITE MATERIALS I}

109718 Structured illumination fiber probe for high-resolution surface feature imaging of 3D printed and composite samples [10971-43]

10971 1 A Enhanced piezoresistive sensing of fiber-reinforced composites via embedded nanoparticles [10971-45]

10971 1B An energy efficient wireless module for on-board aircraft impact detection [10971-46] 
10971 1C Image analysis for classification of damaged and undamaged areas on composite structures [10971-47]

10971 1E Development of a small-scale and low-cost SHM system for thin-walled CFRP structures based on acoustic emission analysis and neural networks [10971-49]

\section{SHM-NDE ULTRASONICS II}

10971 1G Nondestructive evaluation with fully non-contact air-coupled transducer-scanning laser Doppler vibrometer Lamb wave system [10971-50]

$10971 \mathrm{lH} \quad$ Stress change detection from application of a stretching model to coda wave measurements [10971-51]

$1097111 \quad$ Analyzing nonlinear behavior of ultrasound wave in phase-space domain [10971-52]

10971 i J Non-contact excitation of guided waves using air-coupled ultrasonic transmitters for damage detection [10971-53]

10971 1K Measurement of stress wave attenuation in composite laminates [10971-54]

$10971 \mathrm{~L} \quad$ Identifying transition of fatigue cracks from tensile to shear mode based on acoustic emission signals [10971-55]

\section{SHM-NDE OF COMPOSITE MATERIALS II}

10971 iN Eddy current non-destructive evaluation of manufacturing flaws and operational damage in CFRP composites [10971-57]

109710 Acoustic emission localization in composites using the signal power method and embedded transducers [10971-58]

10971 1P A new method for Poisson's ratio measurement with time-of-flight technique: application to the preliminary design of smart composite structures [10971-59]

\section{SHM-NDE SCIENCE AND THEORY III}

10971 1R Direct waveform extraction via a deep recurrent denoising autoencoder [10971-61]

10971 is NDE flaw detectability size estimation using smaller number of hit-miss data-points [10971-62]

$109711 \mathrm{~T} \quad$ Experimental measurements of vibrations of artificial sub-surface cracks and evaluation of identification potential for the electro-mechanical impedance method [10971-63]

10971 IV Application of flexible PAUT probe for weld inspection of piping elbows [10971-73] 
POSTER SESSION

10971 IW Acoustic emission characterization of PVC pipe for various joining types [10971-64]

$109711 \mathrm{~N} \quad$ Numerical simulation of temperature-induced structural strain for a long-span suspension bridge [10971-65]

$109711 Y \quad$ High gain DC-DC converter with coupled inductor [10971-66]

$1097112 \quad$ Ultrasonic determination of the elastic and shear modulus on aged wood [10971-67]

1097120 Estimating the density of wood specimens using synthetic aperture radar imaging [10971-69]

$1097121 \quad$ Measure of in-plane thermal conductivity of composite structures [10971-70]

1097122 Identifying the stiffness reduction in the supporting tower of wind turbines: a numerical approach [10971-71] 
Proc. of SPIE Vol. 10971 1097101-8

Downloaded From: https://www.spiedigitallibrary.org/conference-proceedings-of-spie on 25 Apr 2023 Terms of Use: https://www.spiedigitallibrary.org/terms-of-use 


\section{Authors}

Numbers in the index correspond to the last two digits of the seven-digit citation identifier (CID) article numbering system used in Proceedings of SPIE. The first five digits reflect the volume number. Base 36 numbering is employed for the last two digits and indicates the order of articles within the volume. Numbers start with 00, 01, 02, 03, 04, 05, 06, 07, 08, 09, OA, OB...0Z, followed by 10-12, 20-2Z, etc.

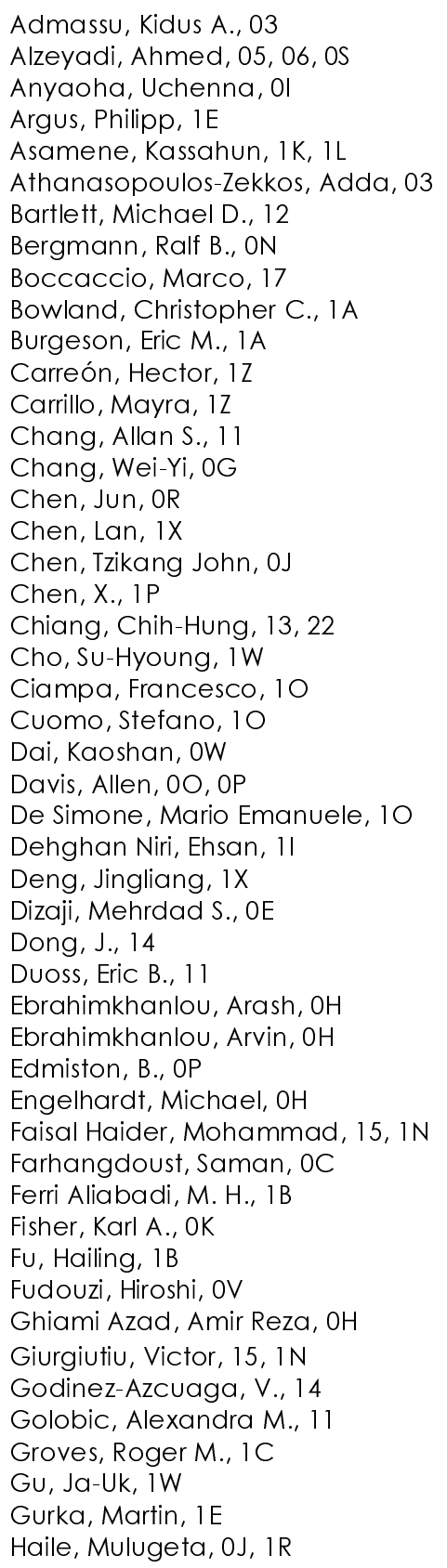

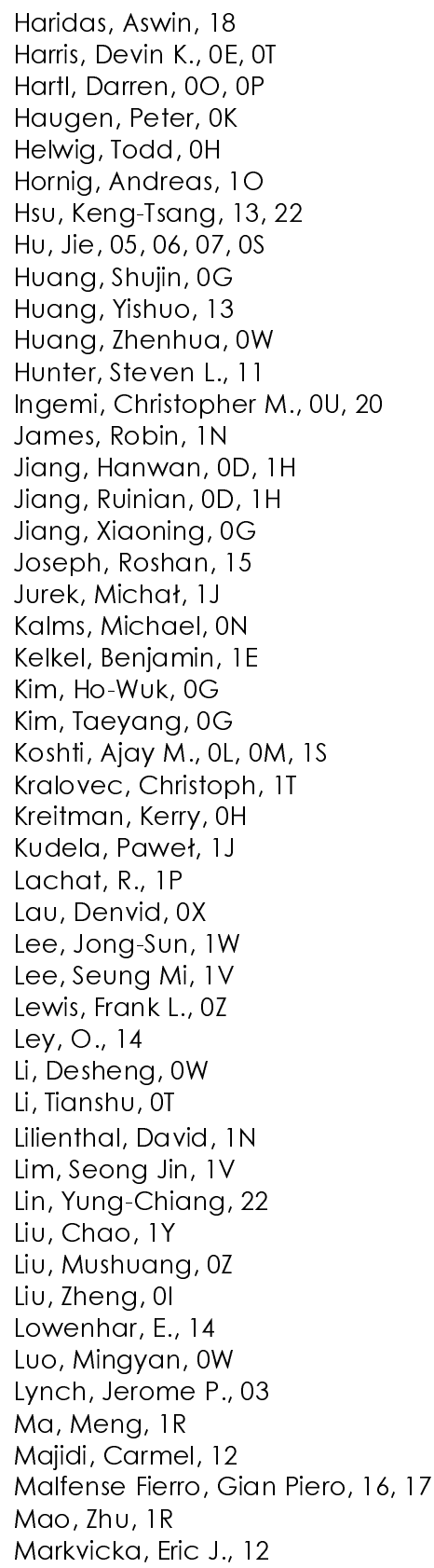


Matthews, Manyalibo J., 11

Mays, Owen, OK

Mehrabi, Armin, oC

Meo, Michele, 16, 17, 10

Meyer, Y., 1P

Mirsayar, Mirmilad, 0O, OP

Modler, Niels, 10

Murukeshan, Vadakke Matham, 18

Naskar, Amit K., 1 A

Nitschke, Sandro, 10

Obenauf, David, OK

Ogura, Yukio, IV

Okudan, Gorkem, 04

Ostachowicz, Wiesław, 1J

Ouisse, M., 1P

Ozevin, Didem, 04, 14

Pan, Huang Hsing, OY

Park, Ik Keun, IV

Park, Tae Sung, $1 \mathrm{~V}$

Peng, Xiang, Ol

Qin, Yang, 1R

Qiu, Qiwen, OX

Radzieński, Maciej, $1 \mathrm{~J}$

Reifsnider, Kenneth, $\mathrm{OZ}$

Rijal, Manoj, 21

Saboonchi, H., 14

Salamone, Salvatore, $\mathrm{OH}$

Schagerl, Martin, IT

Seong, Baek-Min, IW

Sharif Khodaei, Zahra, 1B

Sherfield, Sarai N., 11

Shi, Yuanfeng, OW

Shiao, Michael, OJ

Shrestha, Pratik, 1C

Sripragash, Letchuman, 21

Su, YU-Min, OY

Sun, Hongwei, $1 Y$

Sundaresan, Mannur, 1K, 1L, 21

Tang, Qixiang, 07, OS

Todoroki, Shin-ichi, OV

Tran, Duy, 1K, $1 \mathrm{~L}$

Tsuchiya, Koichi, OV

Tutika, Ravi, 12

Vadlamudi, Vamsee, $0 Z$

Wan, Yan, $\mathrm{OZ}$

Wang, Jenny, 11

Williamson, Eric, $\mathrm{OH}$

Wong, Yong-De, OY

Wu, H. Felix, $\mathrm{OZ}$

Wu, Maochuan, IY

Wu, Yuning, OR

Xiao, Wenfeng, $1 G$

Xin, Song, $1 Y$

$\mathrm{XU}$, Peng, $1 Y$

Yao, Junjie, $1 \mathrm{X}$

Younesian, Davood, OC

Yu, Chih-Peng, 22

Yu, Lingyu, $1 G$

Yu, Tzuyang, 05, 06, 07, 0S, 0U, 20

Zamen, Sina, 11
Zekkos, Dimitrios, 03

Zhan, Hanyu, OD, $1 \mathrm{H}$

Zhang, Jinquan, $\mathrm{OD}, 1 \mathrm{H}$

Zhang, Lu, 04, 14

Zhang, Songhan, OW

Zheng, Zhang, $1 Y$

Zhou, Linren, $1 \mathrm{X}$

Zhuang, Chenxu, $1 \mathrm{H}$ 


\title{
Conference Committee
}

\author{
Symposium Chairs
}

Tribikram Kundu, The University of Arizona (United States)

Gregory W. Reich, Air Force Research Laboratory (United States)

Symposium Co-chairs

Zoubeida Ounaies, The Pennsylvania State University (United States)

Hoon Sohn, KAIST (Korea, Republic of)

Conference Chair

Andrew L. Gyekenyesi, Ohio Aerospace Institute (United States)

Conference Co-chairs

Tzu-Yang Yu, University of Massachusetts Lowell (United States)

H. Felix Wu, U.S. Dept. of Energy (United States)

Peter J. Shull, The Pennsylvania State University (United States)

Conference Program Committee

Gary Carr, Federal Railroad Administration (United States)

Chia-Ming Chang, National Taiwan University (Taiwan)

Genda Chen, Missouri University of Science and Technology (United States)

Chih-Hung Chiang, Chaoyang University of Technology (Taiwan)

Dwight A. Clayton, Oak Ridge National Laboratory (United States)

Kaoshan Dai, Tongji University (China)

Reinhard Ebert, Fraunhofer-Institut für Optronik, Systemtechnik und

Bildauswertung (Germany)

Zhenhua Huang, University of North Texas (United States)

Dryver R. Huston, The University of Vermont (United States)

Xiaoning Jiang, North Carolina State University (United States)

Ajay M. Koshti, NASA Johnson Space Center (United States)

Denvid Lau, City University of Hong Kong (Hong Kong, China)

Shiyuan Liu, Huazhong University of Science and Technology (China)

Kenneth J. Loh, University of California, San Diego (United States)

Jerome P. Lynch, University of Michigan (United States)

Oliver J. Myers, Clemson University (United States)

Piotr Omenzetter, University of Aberdeen (United Kingdom)

Didem Ozevin, University of Illinois at Chicago (United States) 
Akira Sasamoto, National Institute of Advanced Industrial Science and Technology (Japan)

Caesar Singh, United States Deptartment of Transportation (United States)

Yu-Min Su, National Kaohsiung University of Applied Sciences

(Taiwan)

Yan Wan, University of Texas at Arlington (United States)

Ming L. Wang, Northeastern University (United States)

Yang Wang, Georgia Institute of Technology (United States)

Tian Xia, The University of Vermont (United States)

Lingyu Yu, University of South Carolina (United States)

Fuh-Gwo Yuan, North Carolina State University (United States)

\section{Session Chairs}

1 SHM-NDE of Civil Structures/Infrastructure I

Ahmed Alzeyadi, University of Massachusetts Lowell (United States)

Didem Ozevin, University of Illinois at Chicago (United States)

2 SHM-NDE of Civil Structures/Infrastructure ॥

Denvid Lau, City University of Hong Kong (Hong Kong, China)

3 SHM-NDE of Civil Structures/Infrastructure III

Saman Farhangdoust, Florida International University (United States)

Didem Ozevin, University of Illinois at Chicago (United States)

4 SHM-NDE Science and Theory I

Andrew L. Gyekenyesi, Ohio Aerospace Institute (United States)

Tzikang John Chen, U.S. Army Research Laboratory (United States)

5 SHM-NDE of Civil Structures/Infrastructure IV

Ali Abdul Aziz, Kent State University (United States)

Jun Chen, Beihang University (China)

6 SHM-NDE of Civil Structures/Infrastructure V

Denvid Lau, City University of Hong Kong (Hong Kong, China)

Yu-Min Su, National Kaohsiung University of Science and Technology (Taiwan)

7 SHM-NDE Science and Theory II

Chih-Hung Chiang, Chaoyang University of Technology (Taiwan)

Michael Bartlett, lowa State University of Science and Technology

(United States)

8 SHM-NDE Ultrasonics I

Peter J. Shull, The Pennsylvania State University (United States)

Didem Ozevin, University of Illinois at Chicago (United States) 
9 SHM-NDE of Composite Materials I

Christopher C. Bowland, Oak Ridge National Laboratory (United States)

Zahra Sharif Khodaei, Imperial College London (United Kingdom)

10 SHM-NDE Ultrasonics II

Wieslaw M. Ostachowicz, The Szewalski Institute of Fluid-Flow Machinery (Poland)

Ehsan Dehghan-Niri, New Mexico State University (United States)

11 SHM-NDE of Composite Materials II

Victor Giurgiutiu, University of South Carolina (United States)

Ermias Koricho, Georgia Southern University (United States)

12 SHM-NDE Science and Theory III

Zhu Mao, University of Massachusetts Lowell (United States)

Ajay M. Koshti, NASA Johnson Space Center (United States) 
Proc. of SPIE Vol. 10971 1097101-14

Downloaded From: https://www.spiedigitallibrary.org/conference-proceedings-of-spie on 25 Apr 2023 Terms of Use: https://www.spiedigitallibrary.org/terms-of-use 